\title{
PENGARUH MODEL PROBLEM BASED LEARNING TERHADAP HASIL BELAJAR FISIKA SISWA PADA MATERI POKOK LISTRIK DINAMIS DI SMA N I SIANTAR NARUMONDA T. P. 2014/2015
}

\author{
Tertip Hamonangan Siregar dan Usler Simarmata \\ Jurusan Fisika FMIPA Universitas Negeri Medan \\ Jalan Willem Iskandar Pasar V Medan, Sumatera Utara \\ tertiph.siregar@gmail.com
}

\begin{abstract}
ABSTRAK
Penelitian ini bertujuan untuk mengetahui pengaruh model problem based learning terhadap hasil belajar siswa pada materi pokok listrik dinamis di kelas X Semester II SMA N 1 Siantar Narumonda. Populasi dalam penelitian ini adalah seluruh siswa kelas X SMA N 1 Siantar Narumonda T.P 2014/2015 yang terdiri dari delapan kelas. Sampel penelitian dipilih dengan cluster random sampling, kelas X-5 sebagai kelas eksperimen dan kelas X-4 sebagai kelas kontrol dengan masing-masing siswa berjumlah 32 orang. Jenis penelitian ini adalah quasi eksperiment menggunakan control group pretest-posttest design. Instrumen penelitian yang digunakan adalah tes hasil belajar berjumlah 20 soal berbentuk pilihan berganda yang sudah valid dan lembar observasi untuk mengamati aktivitas siswa. Hasil observasi menunjukkan bahwa aktivitas siswa kelas eksperimen meningkat setiap pertemuan, dengan nilai rata-rata masing-masing secara berturut adalah 55, 72 dan 74 . Nilai rata-rata hasil belajar siswa juga meningkat menjadi 75,94. Berdasarkan hasil uji hipotesis menggunakan uji beda (uji $t$ ) menunjukkan bahwa ada pengaruh yang signifikan akibat penerapan model problem based learning terhadap hasil belajar siswa.
\end{abstract}

Kata kunci: model problem based learning, hasil belajar fisika.

\section{ABSTRACT}

This study aims to determine the effect of the model problem based learning on learning outcomes of students at the electrodynamics the material in class X Semester II SMA N 1 Siantar Narumonda. The population in this study were all students of class X SMA N 1 Siantar Narumonda T.P 2014/2015 consisting of eight classes. Samples were selected by random cluster sampling, the class $X-5$ as the experimental class and the class $X-4$ as the control class to each student amounted to 32 people. This research is a quasi experiment using a control group pretest-posttest design. The research instrument used is the multiple choice test total of 20 questions in the form of descriptions that are valid and observation sheet to observe the activity student. Observations indicate that the activity student experiment class is increasing every meeting, with the average value of each 
respectively are 50, 72 and 74 . The average value of achievement of students also increased to 75.94. Based on the results of hypothesis testing using different test ( $t$ test) showed that there was a significant effect due to the application of the model problem based learning to students' learning outcomes.

Keywords: model problem based learning, learning outcomes.

\section{PENDAHULUAN}

Peran pendidikan sangat penting untuk menciptakan masyarakat yang cerdas, damai, terbuka dan demokratis. Pendidikan yang diselenggarakan dengan baik dan bermutu akan menghasilkan manusia yang berkualitas dalam pembangunan nasional.

Peran guru sangat penting dalam mengembangkan potensi dan keterampilan dari setiap siswa karena setiap guru memiliki tanggung jawab yang besar terhadap pelaksanaan pembelajaran dan pencapaian tujuan pendidikan nasional. Namun, kenyataannya salah satu permasalahan pendidikan yang muncul adalah masih rendahnya kualitas pendidikan pada setiap jenjang.

Rendahnya

pendidikan

Indonesia dapat dilihat dari rendahnya hasil belajar siswa dalam berbagai mata pelajaran. Salah satu mata pelajaran yang memiliki nilai rendah adalah mata pelajaran fisika. Fisika merupakan suatu cabang Ilmu Pengetahuan Alam yang mempelajari tentang alam semesta, fenomena alam dan mekanisme yang terjadi di dalamnya. Secara sederhana dapat dikatakan bahwa fisika erat hubunganya dengan kejadiankejadian dalam kehidupan seharihari. Berdasarkan aspek isi fisika, pada dasarnya fisika adalah konsep, hukum, dan teori. Aspek sikap fisikawan adalah ahli dalam melakukan kegiatan fisika. Dengan perkataan lain kecenderungan individu untuk bertindak atau berperilaku dalam memecahkan suatu masalah secara sistematis melalui langkah-langkah ilmiah. Sikap ilmiah dalam menyelesaikan masalah fisika, yakni: sikap ingin tahu, kritis, obyektif, menemukan, menghargai karya orang lain, tekun,dan terbuka. Namun, kenyataanya banyak siswa keliru dalam memahami ilmu fisika, sehingga beranggapan bahwa fisika itu penuh dengan hafalan rumusrumus atau dalil-dalil yang membosankan.

Berdasarkan hasil wawancara peneliti dengan salah satu guru bidang studi fisika SMA N I Siantar Narumonda, menyatakan bahwa hasil belajar fisika masih rendah dengan nilai ulangan harian siswa rata-ratanya masih dibawah 70 . Model pembelajaran yang diterapkan masih kurang bervariasi. Aktivitas belajar siswa juga masih kurang aktif, karena selama proses pembelajaran siswa jarang melakukan percobaan sehingga guru hanya mengevaluasi pada aspek kognitif. Selama proses pembelajaran fisika di kelas, metode yang dominan digunakan guru adalah ceramah, tanya jawab, penugasan, dan siswa diarahkan untuk menghapal informasi serta rumus-rumus, jarang 
siswa dihadapkan terhadap masalahmasalah yang kontekstual.

Berdasarkan

kenyataan

tersebut, perlu diterapkan suatu model pembelajaran yang mampu meningkatkan aktivitas dan hasil belajar fisika siswa. Salah satu alternatif model pembelajaran yang diterapkan adalah model problem based learning (PBL). Ngalimun (2014: 89) menyatakan bahwa model PBL merupakan salah satu model pembelajaran inovatif yang dapat memberikan kondisi belajar aktif kepada siswa. Selain itu Trianto (2010: 92) juga menyatakan bahwa model problem based learning merupakan pendekatan yang efektif untuk pengajaran proses berpikir tingkat tinggi.

Selain Ngalimun dan Trianto, Arends (2008: 41) berpendapat bahwa model PBL merupakan suatu pendekatan pembelajaran dimana siswa mengerjakan permasalahan yang autentik dengan maksud untuk menyusun pengetahuan mereka sendiri, mengembangkan inkuiri dan keterampilan berpikir tingkat lebih tinggi, mengembangkan kemandirian dan percaya diri.

Berdasarkan permasalahan di atas, maka peneliti berkeinginan untuk melakukan penelitian dengan tujuan untuk melihat pengaruh model problem based learning terhadap hasil belajar siswa pada materi pokok listrik dinamis di kelas $\mathrm{X}$ semester II SMA N 1 Siantar Narumonda T.P 2014/2015”.

\section{METODE PENELITIAN}

Populasi dalam penelitian ini adalah seluruh siswa kelas $\mathrm{X}$ semester II SMA N. I Siantar Narumonda T.A 2014/2015 yang terdiri atas 8 kelas. Jenis penelitian ini adalah quasi experiment. Sampel penelitian dipilih dengan cluster random sampling,kelas $\mathrm{X}-5$ sebagai kelas eksperimen yang menerapkan model problem based learning dan kelas $\mathrm{X}^{-4}$ sebagai kelas kontrol yang menerapkan pembelajaran konvensional. Variabel bebas dalam penelitian ini adalah model problem based learning dan pembelajaran konvensional sedangkan hasil belajar siswa pada materi pokok listrik dinamis sebagai variabel terikat. Desain penelitian yang digunakan adalah control group pretest-posttest yang ditunjukkan oleh Tabel 1.

Tabel 1.Control Group Pretest-

Posttest Design (Arikunto, 2006)

\begin{tabular}{|l|c|c|c|}
\hline \multicolumn{1}{|c|}{ Kelas } & Pretes & $\begin{array}{c}\text { Perla } \\
\text { kuan }\end{array}$ & Postes \\
\hline $\begin{array}{l}\text { Eksperime } \\
\text { n }\end{array}$ & $O_{1}$ & $X_{1}$ & $O_{2}$ \\
\hline Kontrol & $O_{1}$ & $X_{2}$ & $O_{2}$ \\
\hline
\end{tabular}

Keterangan:

$O_{1}=$ pretes

$X_{1}=$ model problem based learning

$\mathrm{O}_{2}=$ postes

$X_{2}=$ pembelajaran konvensional

Instrumen penelitian ini adalah

tes hasil belajar berjumlah 20 soal pilihan berganda yang terlebih dahulu divalidkan oleh dua orang dosen jurusan fisika di Unimed dan seorang guru fisika di SMA $\mathrm{N} 1$ Siantar Narumonda. Jumlah soal yang divaliditas sebanyak 20 soal dalam bentuk pilihan berganda. Hasil dari validitas isi menyatakan bahwa soal dikatakan valid dengan kriteria penilaian amat baik dan empat soal perlu diperbaiki kalimat indikatornya.

Teknik analisis yang digunakan untuk menentukan pengaruh model problem based learning terhadap hasil belajar siswa adalah melakukan 
uji hipotesis dengan menggunakan uji beda (uji $t$ ) dengan syarat data harus berdistribusi normal dan bersifat homogen (Sudjana, 2005: 239). Teknik analisis ini dilakukan pada data tes hasil belajar yang diperoleh yaitu data pretes dan postes.

Apabila hasil pretes kedua kelas memiliki kesamaan rata-rata berarti kemampuan awal kelas eksperimen sama dengan kemampuan awal siswa pada kelas kontrol. Apabila hasil postes kelas eksperimen yang menerapkan model problem based learning lebih tinggi dari kelas kontrol dengan pembelajaran konvensional, berarti ada perbedaan hasil belajar yang signifikan akibat penerapan model problem based learning, sehingga dapat disimpulkan bahwa model ini ada pengaruhnya terhadap hasil belajar siswa.

\section{HASIL DAN PEMBAHASAN Hasil Penelitian}

Nilai rata-rata pretes untuk kelas eksperimen dan kontrol secara berurutan adalah 39,53 dan 40,16. Data pretes berdistribusi normal dan homogen, maka dilakukan uji hipotesis data pretes menggunakan uji $t$. Berdasarkan hasil perhitungan uji $t$, makadisimpulkan bahwa siswa kelas eksperimen dengan siswa kelas kontrol mempunyai kemampuan awal yang sama. Untuk melihat secara rinci hasil pretes kedua kelas dapat dilihat pada Gambar 1.

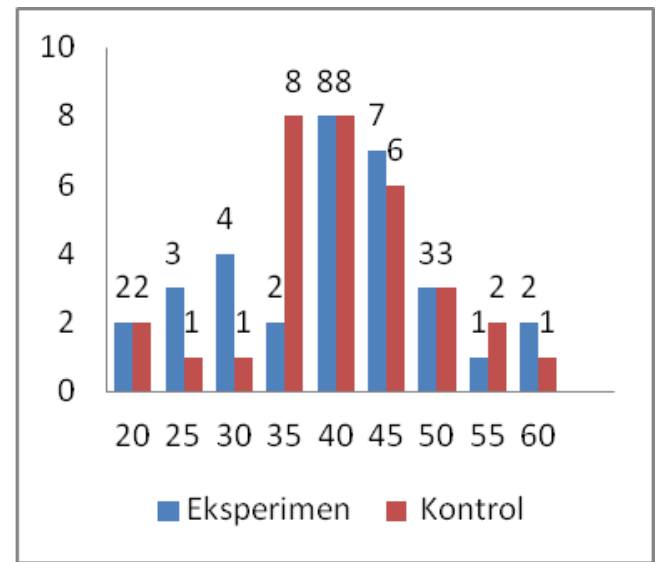

Gambar 1. Diagram batang pre tes kelas eksperimen dan kontrol

Setelah selesai proses pembelajaran dimana pada kelas eksperimen digunakan model problem based learning sedangkan pada kelas kontrol menggunakan pembelajaran konvensional, maka dilakukan postes untuk mengetahui ada tidaknya perbedaan antara pretes dan postes.Nilai rata-rata postes untuk kelas eksperimen dan kontrol secara berurutan adalah 75,94 dan 64,38. diperoleh hasil postes kedua kelas pada Gambar 2.

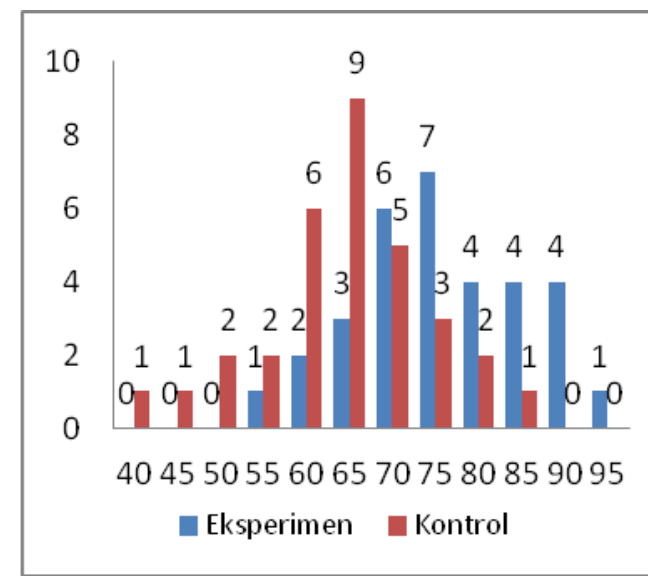

Gambar 2. Diagram batang pos tes kelas eksperimen dan kontrol

Data postes berdistribusi normal dan homogen, maka dilakukan uji hipotesis data postes menggunakan uji $t$. Berdasarkan hasil perhitungan uji $t$, disimpulkan 
bahwa ada pengaruh model problem based learning yang signifikan terhadap hasil belajar siswa pada materi pokok listrik dinamis di kelas X SMA N 1 Siantar Narumonda.

Selama proses pembelajaran, pengamatan aktivitas siswa dilakukan tiga kali pertemuan setelah melakukan pretes. Observasi aktivitas ini dilakukan di kelas eksperimen yang sesuai dengan penerapan model pembelajaran yang digunakan. Aspek aktivitas yang dinilai adalah merumuskan hipotesis, melakukan diskusi, melakukan percobaan, memecahkan masalah dan mempresentasikan hasil karya. Ratarata aktivitas siswa kelas eksperimen ditunjukkan pada Gambar 3.

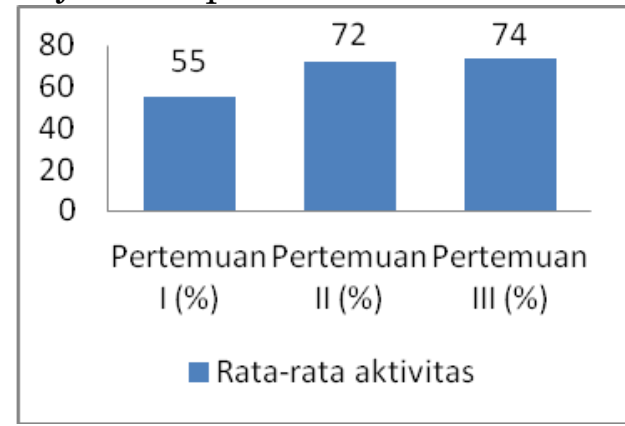

Gambar 3. Diagram Batang Aktivitas

Aktivitas siswa kelas eksperimen meningkat di setiap pertemuan. Kelas kontrol tidak memiliki penilaian aktivitas karena aktivitas pada kelas kontrol tidak cocok dengan kelima aspek penilaian aktivitas tersebut. Hal ini disebabkan karena pada kelas kontrol, guru yang lebih berperan aktif daripada siswa. Siswa hanya mendengarkan, mencatat dan mengerjakan soal yang diberikan oleh guru.

\section{Pembahasan}

Hasil penelitian menunjukkan bahwa ada pengaruh yang signifikan antara hasil belajar siswa dengan model pembelajaran Problem Based
Learning dan pembelajaran konvensional pada materi pokok listrik dinamis kelas X semester II di SMA N I Siantar Narumonda T.P 2014/2015. Hal ini diperkuat dengan perolehan nilai rata-rata pretes siswa di kelas eksperimen sebesar 39,53 dan nilai rata-rata postes sebesar 75,93 . Sedangkan di kelas kontrol diperoleh nilai rata-rata pretes siswa sebesar 40,16 dan nilai rata-rata postes sebesar 64,38 .

Nilai pretes dan postes siswa beserta nilai aktivitas belajar siswa pada kelas eksperimen diperoleh bahwa hasil belajar siswa pada pretes memiliki kriteria sangat kurang secara keseluruhan. Namun dengan adanya aktivitas siswa pada kelas eksperimen, hasil belajar siswa yang diperoleh dari hasil postes mengalami peningkatan. Terdapat 13 siswa yang memiliki kriteria sangat baik, 18 siswa yang memiliki kriteria baik, dan hanya ada 1 siswa yang memiliki kriteria cukup. Sedangkan ditinjau dari segi aktivitas siswa berdasarkan keaktifanya, terdapat 9 siswa tergolong sangat aktif, 12 siswa dengan kriteria aktif, 4 siswa dengan kriteria cukup aktif, dan 11 siswa tergolong kriteria kurang aktif.

Dari hasil penelitian yang dilakukan didapat bahwa siswa yang memiliki kriteria pretes sangat kurang, kriteria aktivitas sangat aktif dan kriteria postes sangat baik (SKSASB) berjumlah 5 siswa ; kriteria pretes sangat kurang, kriteria aktivitas sangat aktif dan kriteria postes baik (SKSAB) berjumlah 4 siswa; siswa yang memiliki kriteria pretes sangat kurang, kriteria aktivitas aktif dan kriteria postes sangat baik (SKASB) berjumlah 4 siswa; siswa yang memiliki kriteria pretes sangat kurang, kriteria aktif dan kriteria 
postes baik (SKAB) berjumlah 7 siswa; siswa yang memiliki kriteria pretes sangat kurang, kriteria aktivitas aktif dan kriteria postes cukup (SKAC) berjumlah 1 siswa; siswa yang memiliki kriteria pretes sangat kurang, kriteria aktivitas cukup aktif dan kriteria postes sangat baik (SKCASB) berjumlah 4 siswa; siswa yang memiliki kriteria pretes sangat kurang, kriteria aktivitas cukup aktif dan kriteria postes baik (SKCAB) berjumlah 7 siswa.

Berdasarkan hubungan antara nilai pretes, nilai aktivitas dan nilai postes siswa pada kelas eksperimen yang disusun berdasarkan nilai aktivitas terendah ke nilai aktivitas tertinggi dapat dilihat pada Gambar 4.

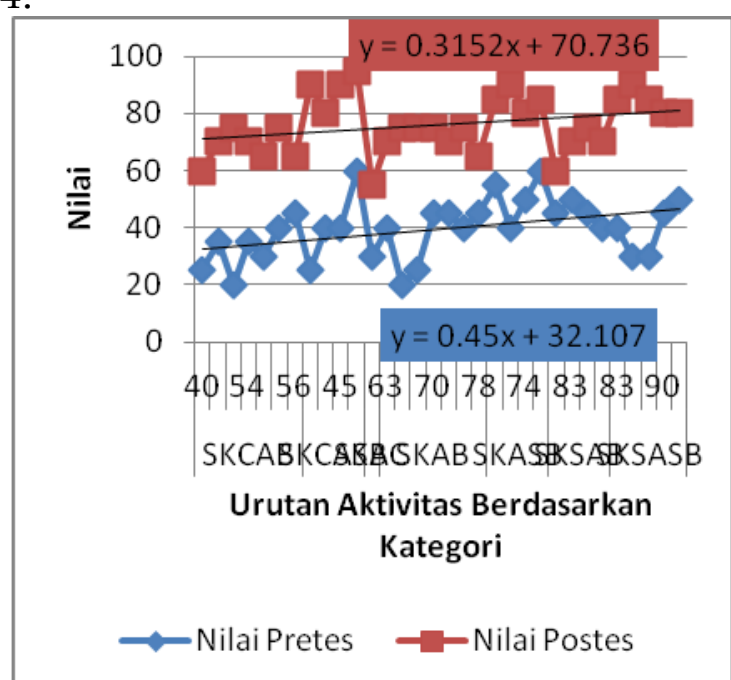

Gambar 4. Grafik Nilai Pretes, Aktivitas dan Postest berdasarkan kategori dari yang paling rendah sampai yang paling tinggi.

Persamaan linier $\mathrm{y}=\mathrm{ax}+\mathrm{b}$ memiliki nilai a yang menyatakan kemiringan garis. Jika dilihat dari grafik, nilai a pada $\mathrm{y}_{\text {post }}=0,3152 x+70,736 \quad$ lebih kecil dibandingkan dengan nilai a pada $\mathrm{y}_{\text {pre }}=0,45 \mathrm{x}+32,107$. Nilai a pada persamaan linier pretes (apre) menjadi acuan kriteria dalam menentukan berpengaruh atau tidaknya nilai aktivitas. Adapun kriterianya adalah sebagai berikut:

$a_{\text {post }}<a_{\text {pre }}$ : nilai aktivitas tidak mempengaruhi hasil belajar (nilai postes)

$a_{\text {post }}>$ apre : nilai aktivitas mempengaruhi hasil belajar (nilai postes)

Hal ini menunjukkan $a_{\text {post }}>a_{\text {pre }}$ yang berarti nilai aktivitas mempengaruhi hasil belajar (nilai postes). Grafik diatas menunjukan bahwa hasil belajar tidak dipengaruhi oleh aktivitas karena nilai a pada postes lebih kecil dari nilai a pada pretes.

Berdasarkan hubungan antara nilai pretes, nilai aktivitas dan nilai postes siswa. Berikut ini ditampilkan grafik hubungan antara nilai pretes, nilai aktivitas dan nilai postes siswa pada kelas eksperimen yang disusun berdasarkan nilai terendah ke nilai tertinggi dapat dilihat pada Gambar 5 .

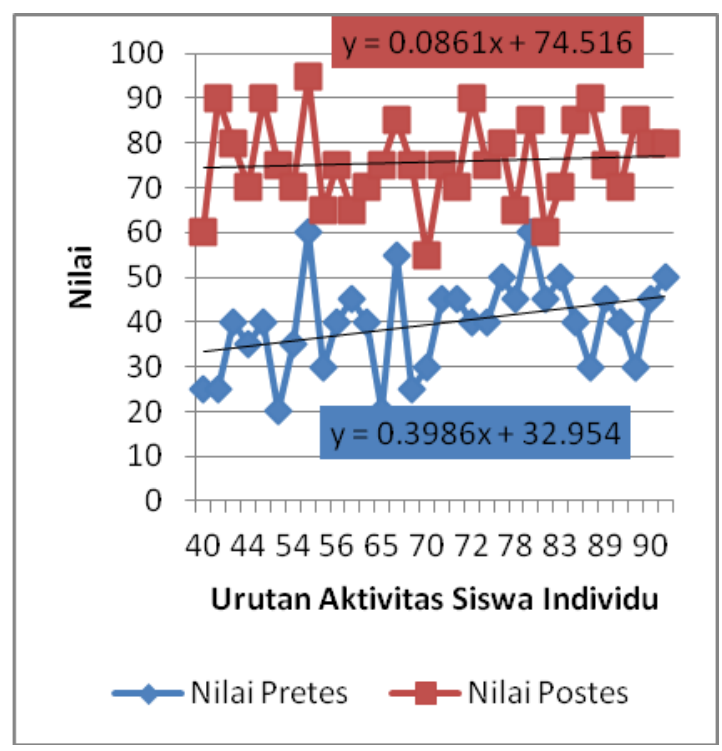

Gambar 5. Grafik nilai Pretest, Aktivitas dan Postes berdasarkan individu urutan terendah sampai tertinggi. 
Persamaan linier $y=a x+b$ memiliki nilai a yang menyatakan kemiringan garis. Jika dilihat dari grafik, nilai a pada $\mathrm{y}_{\text {post }}=0,0861 \mathrm{x}+74,516 \quad$ lebih kecil dibandingkan dengan nilai a pada $\mathrm{y}_{\text {pre }}=0,3986 \mathrm{x}+32,954$.

Hal ini menunjukkan $a_{\text {post }}<$ apre yang berarti nilai aktivitas tidak mempengaruhi hasil belajar (nilai postes). Pelaksanaan model pembelajaran dikatakan berhasil apabila nilai a postes minimal sama dengan nilai a pretes. Namun dari grafik tampak bahwa nilai $\mathrm{a}_{\text {post }}<\mathrm{a}_{\text {pre, }}$ yang menunjukkan bahwa nilai aktivitas tidak mempengaruhi hasil belajar (nilai postes).

Berdasarkan hubungan antara nilai pretes, nilai aktivitas dan nilai postes siswa. nilai siswa perkelompok dapat disusun berdasarkan urutan nilai rata-rata perkelompok dari urutan nilai rata-rata aktivitas terendah ke nilai rata-rata tertinggi. Secara lebih rinci data tersebut dapat dilihat pada Gambar 6.

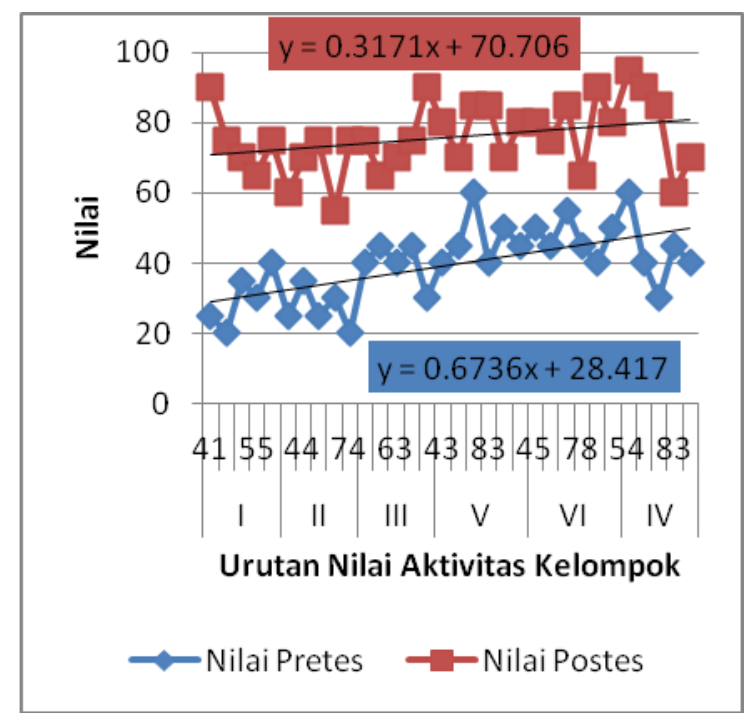

Gambar 6. Grafik hubungan nilai pretes, aktivitas dan postes siswa pada kelas eksperimen berdasarkan urutan nilai rata-rata kelompok.
Persamaan linier $\mathrm{y}=\mathrm{ax}+\mathrm{b}$ memiliki nilai yang menyatakan kemiringan garis. Jika dilihat dari grafik, nilai a pada $\mathrm{y}_{\text {post }}=0,3171 x+70,706$ lebih kecil dibandingkan dengan nilai a pada $\mathrm{y}_{\text {pre }}=0,6736 \mathrm{x}+28,417$. Hal ini menunjukkan $a_{\text {post }}<a_{\text {pre }}$ yang berarti nilai aktivitas tidak mempengaruhi nilai hasil belajar (nilai postes).

Gambar 4. 5 , dan 6 merupakan grafik nilai aktivitas siswa dalam proses, individu dan kelompok yang diurutkan dari nilai terendah ke tertinggi yang masingmasing memiliki persamaan linier, karena nilai apre pada ketiga gambar selalu lebih besar dari pada a post maka pelaksanaan model problem based learning kurang berjalan dengan baik dan tidak mempengaruhi hasil belajar, hal ini disebabkan karena peneliti belum memahami tahap/sintax model problem based learning dengan benar.

Berdasarkan penelitian yang dilakukan oleh Sinemaso H. Manik (2014: 64) ditemukan bahwa aktivitas belajar siswa tidak berpengaruh terhadap hasil belajar siswa, hal ini terlihat dari gambar grafik persamaan linear aktivitas proses, aktivitas individu dan aktivitas kelompok yang menunjukkan a ast < $a_{\text {pret }}$ pada setiap persamaan linear.

Kegiatan pembelajaran berbasis masalah yang diawali dengan pemberian masalah pada siswa, selanjutnya siswa melakukan eksperimen secara kelompok agar saling bekerjasama dan berkolaborasi untuk mendapatkan jawaban masalah yang diajukan. Kegiatan seperti ini menungkinkan siswa bertukar pikiran dan berdiskusi 
dengan temannya sehingga siswa sendirilah yang menemukan jawaban masalahnya bukan karena diberi tahu oleh guru. Berbeda halnya dengan pembelajaran konvensional yang menganggap siswa sebagai botol kosong yang siap diisi oleh guru tanpa memberikan siswa kesempatan untuk berpikir, berbuat dalam menemukan suatu konsep, kondisi ini mengakibatkan siswa hanya menghafal konsep-konsep fisika itu sendiri tanpa memahami proses dan gejalanya terjadi. Sejalan dengan pendapat Setyorini, dkk (2011: 53) bahwa dengan demikian penerapan pembelajaran berbasis masalah juga membantu siswa dalam meningkatkan kemampuan berpikir kritis dan hasil belajar siswa.

Berdasarkan hasil penelitian yang dilakukan oleh Eldy, et all., (2013: 24) menyatakan bahwa ada perbedaan yang signifikan antara hasil belajar serta keterampilan berpikir kreatif dan kritis mahasiswa yang yang menggunakan model problem based learning. Peran guru di kelas eksperimen yang menerapkan model problem based learning tidak hanya ceramah di dalam ruangan tetapi siswa langsung dihadapkan pada eksperimen yang mendukung teori tersebut, sehingga hal itu dapat membantu meningkatkan rasa percaya diri siswa dan menjadi aktif dalam pembelajaran dan keterampilan sosial siswa menjadi berkembang.

Berdasarkan hasil penelitian terdahulu yang dilakukan oleh Selcuk (2010: 720) menyatakan bahwa mengajar ilmu fisika menggunakan model problem based learning jauh lebih efektif keberhasilannya daripada menggunakan pembelajaran konvensional. Selain itu, model problem based learning juga dapat meningkatkan hasil belajar secara berkelompok bukan hanya secara individu. Pembelajaran berdasarkan masalah merupakan teknik yang cukup bagus untuk lebih memahami isi pelajaran dan membantu siswa bagaimana mentransfer pengetahuan mereka untuk memahami masalah dalam kehidupan nyata.

Berdasarkan penelitian yang dilakukan oleh Derlina, dkk., (2013: 427) didapat bahwa dengan menerapkan model pembelajaran berbasis masalah dapat meningkatkan hasil belajar siswa yang lebih baik dibandingkan dengan hasil belajar siswa yang diajarkan dengan model pembelajaran konvensional.

Namun, masih ada beberapa kendala yang dihadapi selama pembelajaran. Salah satu kendala yang terjadi adalah ketika mengorganisasikan siswa dalam kelompok, menggunakan waktu yang cukup lama karena siswa di kelas ini belum terbiasa dalam pembentukan kelompok sebelumnya. Rasa malu dan ragu dalam pengambilan kesimpulan masih tertanam pada diri siswa, sehingga siswa mengalami kesulitan dalam membuat kesimpulan hasil kerja kelompoknya. Peneliti juga mengalami kendala dalam mengawasi siswa dalam setiap kelompok karena observer yang dilibatkan terbatas. Permasalahan yang diberikan pada saat fase pertama seharusnya adalah masalah yang berbeda untuk setiap kelompok agar dapat melihat cara berpikir siswa yang lebih kreatif. Namun, peneliti mengalami kendala karena peneliti tidak mempunyai waktu yang cukup untuk membuat soal berbasis masalah dalam setiap kelompok

Berdasarkan hasil penelitian yang dilakukan, terdapat perbedaan 
hasil belajar dan hasil observasi aktivitas antara kelas eksperimen dengan kelas kontrol. Hasil penelitian menunjukkan bahwa ada pengaruh yang signifikan model problem based learning terhadap hasil belajar siswa pada materi pokok listrik dinamis di Kelas X Semester II SMA N 1 Siantar Narumonda T.P 2014/2015.

\section{KESIMPULAN DAN SARAN}

Kesimpulan

Berdasarkan hasil penelitian yang diperoleh maka dapat disimpulkan bahwa hasil belajar siswa dengan menggunakan model problem based learning pada materi pokok listrik dinamis memberikan nilai rata-rata dengan kategori baik. Hasil belajar siswa dengan menggunakan pembelajaran konvensional khususnya pada materi listrik dinamis memberikan nilai rata-rata dengan kategori cukup baik. Ada pengaruh yang signifikan akibat model problem based learning terhadap hasil belajar siswa pada materi listrik dinamis di kelas $\mathrm{X}$ Semester II SMA N 1 Siantar Narumonda T.P 2014/2015.

Aktivitas siswa yang dikembangkan dari model problem based learning dapat meningkatkan keaktifan siswa dalam proses pembelajaran dengan kategori ratarata aktivitas di setiap pertemuan dinyatakan aktif.

\section{Saran}

Sangat dibutuhkan pemahaman dalam menggunakan model problem based learning dengan benar sesuai tahapanya, sebagai salah satu upaya untuk membuat siswa lebih aktif dalam pembelajaran, menambah kreativitas, semangat belajar siswa, serta meningkatkan hasil belajar siswa.

Peneliti selanjutnya yang ingin meneliti tentang model pembelajaran berdasarkan masalah lebih lanjut, disarankan untuk lebih memperhatikan efisiensi waktu pada tahap "mengembangkan dan menyajikan hasil karya", karena pada tahap ini hampir semua siswa ingin menampilkan hasil diskusi mereka.

\section{DAFTAR PUSTAKA}

Arends, R., (2008), Learning to Teach: Belajar untuk mengajar, Pustaka Pelajar, Yogyakarta

Arikunto, S. (2010). Prosedur Penelitian Suatu Pendekatan Praktik, Rineka Cipta, Jakarta

Derlina, (2013). Pengaruh Model Pembelajaran Berbasis Masalah terhadap Hasil Belajar Siswa Pada Materi Pokok Optik Geometri kelas X SMA St.Yoseph Medan. Prosiding Semirata FMIPA Universitas Lampung, 2013

Eldy, E., and Sulaiman, F., (2013), Integrated PBL Approach: Preliminary Findings towards Physics Students' Critical Thinking and Creative-Critical Thinking, International Journal of Humanities and Social Science Invention, Volume 2 Issue 3, pp.18-25

Manik, S.H., (2014), Pengaruh Model Pembelajaran Problem Based Learning terhadap hasil belajar siswa pada materi pokok kinematika gerak lurus kelas $\mathrm{X}$ semester I SMA Negeri 11 Medan T.P 2013/2014., Skripsi. Medan: FMIPA Unimed.

Ngalimun, (2014), Strategi dan Model Pembelajaran, Aswaja Pressindo, Banjarmasin 
Pulungan, F.R (2012). Pengaruh Model Pembelajaran Problem Based Learning Berbasis Pendidikan Karakter Terhadap Perubahan Karakter Dan Kemampuan Menyelesaikan Masalah Fisika. Medan: Jurnal Penelitian Inovasi Pembelajaran Fisika. Vol. 4, No. 2: 38-43

Selcuk, G. S., (2010), The effects of problem-based learning on preservice teachers' achievement, approaches and attitudes towards learning physics, International Journal of the Physical Sciences Vol. 5(6), pp. 711-723

Setyorini., Sukiswo., dan Subali., (2010), Penerapan Model Problem Based Learning untuk Meningkatkan Kemampuan Berpikir Kritis Siswa SMP, Jurnal Pendidikan Fisika Indonesia 7 (2011): 52-56

Sudjana, (1992), Metoda Statistika, Penerbit Tarsito, Bandung

Trianto, (2010), Mendesain Model Pembelajaran InovatifProgresif, Kencana, Jakarta 